\title{
ANAL YSIS OF THE HERALDIC ELEMENTS IN THE BUILDING AND IN THE DOCUMENT DATED 1715 THAT WAS ISSUED FOR THE ANTIM MONASTERY IN BUCHAREST, ROMANIA
}

DOI: http://dx.doi.org/10.18509/GBP.2020.69

UDC: $726.7(498)$

\author{
Laurentiu Stefan Szemkovics ${ }^{1}$ \\ Camelia Teodorescu ${ }^{2}$ \\ Vasile Pop $^{3}$ \\ Andrei Ducman ${ }^{2}$ \\ Mihaela Gadoiu ${ }^{4}$ \\ ${ }^{1}$ National Central Historical Archives, Bucharest, Romania \\ ${ }^{2}$ Faculty of Geography, CAIMT (Research Center for Integrated Analysis and Territorial \\ Management), University of Bucharest, Romania \\ ${ }^{3}$ St. Elefterie Church, Bucharest, Romania \\ ${ }^{4}$ University of Pitesti, Faculty of Economic and Law Sciences, Department of Finance, \\ Accounting and Economics, Romania
}

\begin{abstract}
The study aims to highlight the letter issued by Antim Ivireanul, the metropolitan of the Romanian Country between 1708 and 1716, [15], [14], [24], [5], [18], in which he mentions how the Monastery of All Saints in Bucharest (today called Antim Monastery) was built, to be an example to be followed in a 32-headed settlement, the coat of arms of the above mentioned founder, as well as the heraldic elements painted on the document, or carved in this place of worship in the capital of Romania. For the preparation of the present study we researched the funds of documents located at the Central National Historical Archives and at the Antim Monastery in Bucharest. Regarding the actual description of the different types of coat of arms, we have complied with the heraldic norms and the recommendations of the former International Sigilography Committee. When designing this study, we considered the interest that these heraldic compositions (paintings or sculptures) may present for teachers, pupils, students, as well as for the general public. I considered that in the modernization stage of the instructionaleducational process, heraldic sources can serve to the better understanding of some historical phenomena, especially concerning the marks used during the time of the ancestors, but can also help to decipher the symbols by which the ancestors have expressed aspirations. At the same time, the study constitutes an impetus for the intensification of the actions meant to detect, preserve and introduce these testimonies of the past into the scientific circuit.
\end{abstract}

Keywords: monastery, coat of arms, metropolis, monastery, heraldry

\section{INTRODUCTION}

The religious and cultural objectives are great tourist attractions today, where tourists can enrich their knowledge and level of culture. At the resource locations included in the present study, as for instance Antim Monastery in Bucharest, Antim Monastery Museum, National Archives of Romania, Romanian Academy Library and Brancovan Palace in Mogoșoaia, Dâmbovița county, tourists can discover religious art, sculpture, architecture, 
blazons and they can research documents and other material traces that refer to the objectives to be visited.

I have described and reproduced the heraldic compositions that are preserved in the institutions mentioned above, which were painted, dedicated or belonged to Antim Ivirean, the metropolitan of the Romanian Country (1708-1716).

In our study we did not insist on the content of the acts that included these heraldic signs, on their importance as historical sources. We insisted on the description, reproduction and symbolism of the coat of arms which, by reflecting with great fidelity the historical era in which it was created, may contribute to highlighting the artistic activity of the issuer, constituting a rich resource for painting and sculpture from the Middle Ages and the modern era.

This presentation is part of the series of manifestations meant to praise on the famous Romanian metropolitan, especially in 2016, at the 300th anniversary of his death, it was declared, at the initiative of Patriarch Daniel and the Holy Synod of the Romanian Orthodox Church, "The commemorative year of Saint Hierarch Martyr Antim Ivirean and of the church printers".

\section{METHODOLOGY}

Regarding the method performed in this study, we went through the following steps:

1. Identification of the institutions in Romania where Antim's heraldic compositions are, or are simply connected to, or concern the metropolitan;

2. Visiting these buildings and researching the heraldic remains, whether they were reproduced on paper, parchment or any other material;

3. Analysing the coats of arms and flag heraldry by taking into account the heraldic norms and the recommendations of the former International Sigilography Committee, a body created in 1959 by the decision of the Executive Bureau of the International Archives Council;

4. Bringing these testimonies of the past to the knowledge of the interested public, through different manifestations, visits, works or specialized studies, as well as by promoting, for tourist purposes, the ecclesiastical heraldic testimonies and the institutions holding them.

\section{RESULTS}

A. At the Central National Historical Archives of Bucharest, the "Suluri" collection, no. 13, there is the archbishop - solemn document of Antim's archery of July 20, 1715 (figure 1). It is written on parchment $(111 \times 47 \mathrm{~cm})$, in Romanian, with Cyrillic characters, by Nicola Ierei, the notary of the Metropolis and signed by the Metropolitan Antim. In the document it is specified how the Monastery of All Saints in Bucharest was built and that it was meant to be an example to follow, establieshed by a 32 headed settlement [13], [16], [17], [2], [1], [22], [19].

The frontispiece of the solemn document, rectangular in shape $(34 \times 14.5 \mathrm{~cm})$, with golden background, with vegetal and floral ornaments of different colours, includes, in the middle, an oval shield $(15 \times 12 \mathrm{~cm})$, with thin golden border, diplaying a green plain, over which the building of the Antim Monastery, silver, with the roof and the golden crosses, surmounted by a cruciferous golden globe that has above a laurel wreath symbolizing victory, of the same metal, held by a hand of two angels, with the golden haloes, wings and vestments, the other hand of each angel holding a green palm branch - 
symbol of regeneration and immortality resting on the shoulder, depicted in kneeling position on a purple cloud [3], [25].

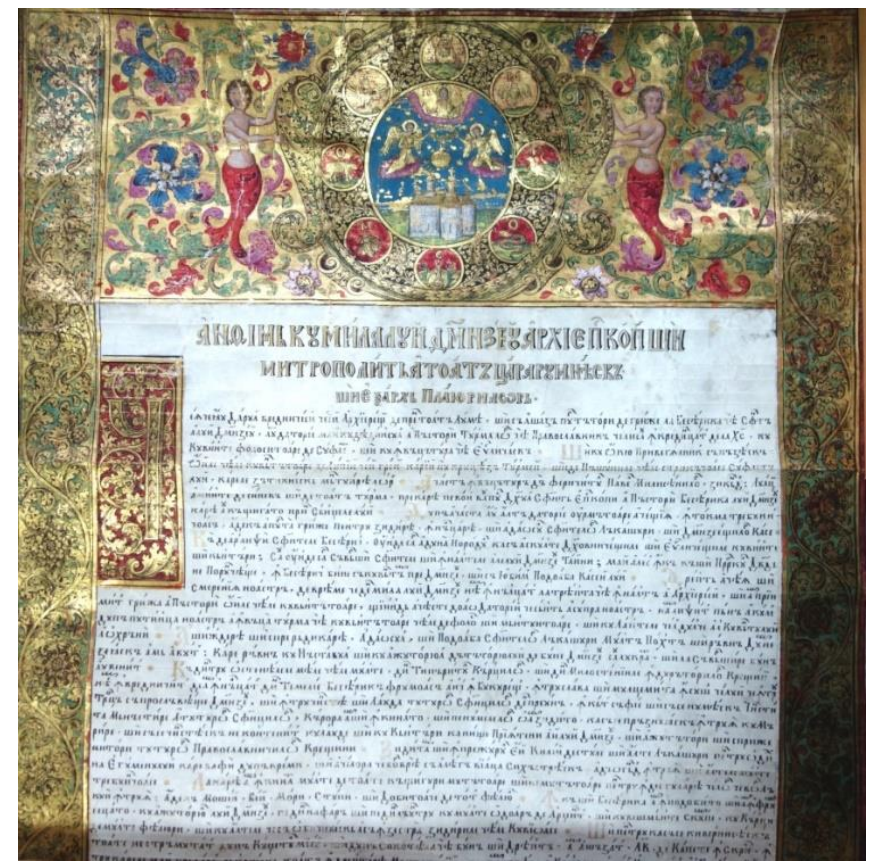

Figure 1. Royal document of Archbishop Antim issued on July 20, 1715 (beginning part)

The sky is blue, sprinkled with golden little stars, with six rays. At the top of the shield, on a golden background, there is Jesus, coming out of the clouds, also purple, flanked, at the level of the head, both rightside and leftside, by the red letters: IS - HS (rendered in Romanian, with Cyrillic characters). This part of the frontispiece can also be found, in the form of a sketch, in the Library of the Romanian Academy [17]. The shield is included in a golden oval garland, adorned on the edges, with four golden baroque motifs; the bottom between the garland and the shield is black, loaded with golden acanthus leaves and eight other smaller, round shields, with a thin, golden border, encompassing, above, the attributes of a metropolitan's dignity - on a red background, a green plain, over which it broaches the cross and the crutch, placed in a portion called ,saritoare" - an honorabke part of the coat of arms, connected, towards the extremities, by the cords on the flanks of the dignitary hat that surmounts - is above, the mitra. The other seven shields contain symbols accompanying each of the seven letters, capital letters, gilded, which make up the name of Antim, with Greek characters: ANOIMOC. Thus, the shields are fully coloured as follows: the one on the upper left - red, with a golden eagle, fully rendered, front- view positioned, with the wings are open and the body contoured - expression referring to animals or animal heads looking towards the left of the shield, head to the right, standing on a green plain and having letter A just above; the one on the top right in red colour, with a gilded bat - it means rebirth, kindness, rendered entirely and frontview positioned, with open wings, placed above a green field and accompanied at the top by the letter N; the one on the left - in red, with a jackal - symbolizing justice of gold, well- contoured, sitting on a green plain and the letter $\Theta$; the one on the right - in red, with a golden hawk - meaning warrior spirit, noble and just [4], standing on green mountains and bearing above the letter I; the one on the bottom leftside- in red, with a gilded bee - symbol of hardness, diligence, work and order [4], with the letter M on top; the one on the bottom rightside - in red, with a gilded snake - symbol of penetration, 
knowledge, immortality, fertility and prophecy [4] standing on green mountains and with the letter O; the one below contains the emblem of Metropolitan Antim, that is, on a red background, a gilded snail, positioned on a green plain, flanked by two branches of green palm-tree coming out from under his shell, having a star of the same metal just between the horns, while above there stands the letter $\mathrm{C}$. The snail indicates the periodic regeneration, death and rebirth, the theme of the eternal return. The snail also signifies fertility, the movement within the permanence, the return of spring after winter, humility, faith [3], [4]. The so-called ,palul” - the pale is the honorable piece of the shield obtained by drawing two vertical lines in the center of the shield [12], [10], [8].

The garland has, on its flanks, as supporters, on a green background, two modillions of golden acanthus leaves, and as tenants - human characters supporting the shield, two melusines - symbolizing traditional knowledge and culture, waist- tied with one golden belt - symbol of the union, with the underside composed of red acanthus leaves and two purple lined tails, rendered entirely and front- viewed, with curly hair, head turned outward, holding the modillions in both hands.

The initials of the words that designate, in ancient Greek, the natural heraldic figures that accompany the letters that make up the name of the metropolitan Antim, are acrostiches, namely: $A E T O \Sigma$ (reading: aetós) - eagle; NYKTEPI $\Sigma$ (read: nicterís) - liliac; $\Theta \Omega O \Sigma$ (reading: thós) - jackal; IEPA $\Xi$ (read: iérax) - hawk; ME $\Lambda \mathrm{I} \Sigma \Sigma \mathrm{A}$ (reading: melissa) - bee; 'ОФI $\Sigma$ (read: ófis) - snake; $\Sigma$ A $\Lambda$ IГKAPI (read: salingári) - snail. [18]

B. At the Library of the Romanian Academy [17] and at the Brancovan Palace in Mogoşoaia, there is painted, in a painting, the coat of arms of the Metropolitan Antim (figure 2), namely: shield, with a thin border, golden, with baroque ornaments on the flanks and on the upper edge, with two small concavities on the flanks and with the tip in a brace, red, loaded with a silver snail, positioned in the pale, standing on a green plain and having a gold star with six rays just between the two tentacles on the head.

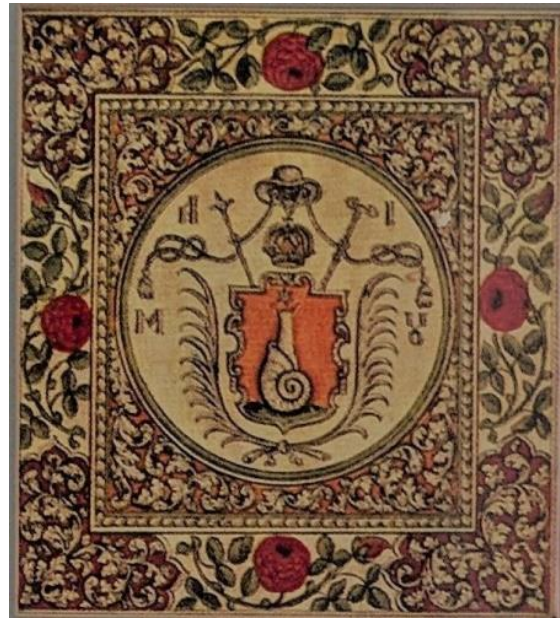

Figure 2. The coat of arms of Antim Ivireanul (Library of the Romanian Academy).

The shield has two palm branches on the flanks that intersect, in leaps, under the tip. The shield is surmounted by the miter that has above the dignitary/tarp hat whose cord strings are wrapped, in the middle of them, by the cross and the crutch, that protrudes from the top edge. Around, the golden capital letters appear: A - I / M - U (Antim Ivireanul/Metropolitan of Ungrovlahiei). The heraldic composition is inscribed in a round medallion, with two edges, one green on the inside, the other silver on the outside, inscribed in a rectangle with the golden edges, the linear outer one and the pearly inner 
one; the inner background is red sprinkled with golden arabesques. The rectangle is, in turn, framed in a rectangular frame, with golden edges. The inner bottom between the two rectangular frames is, at the corners, purple loaded with golden acanthus plants, and in the middle, next to the four cardinal points, golden charged with four green mulberry plants, equipped with four red flowers, buttoned - with the pistil black, arranged in a cross. C. Antim Monastery in Bucharest, with the dedication "All Saints", was erected, between 1713-1715, on the place of a wooden church dedicated to St. Nicholas [17], [11], [6]. In front of this religious edifice there is a black bronze sculpture, depicting Antim, in which the metropolitan is rendered entirely and front-view positioned, sitting on a column covered with marble plates, with his head slightly bent in front and his eyes looking down, with the right hand in a blessing position, the left holding the metropolitan crutch (figure $3)$.

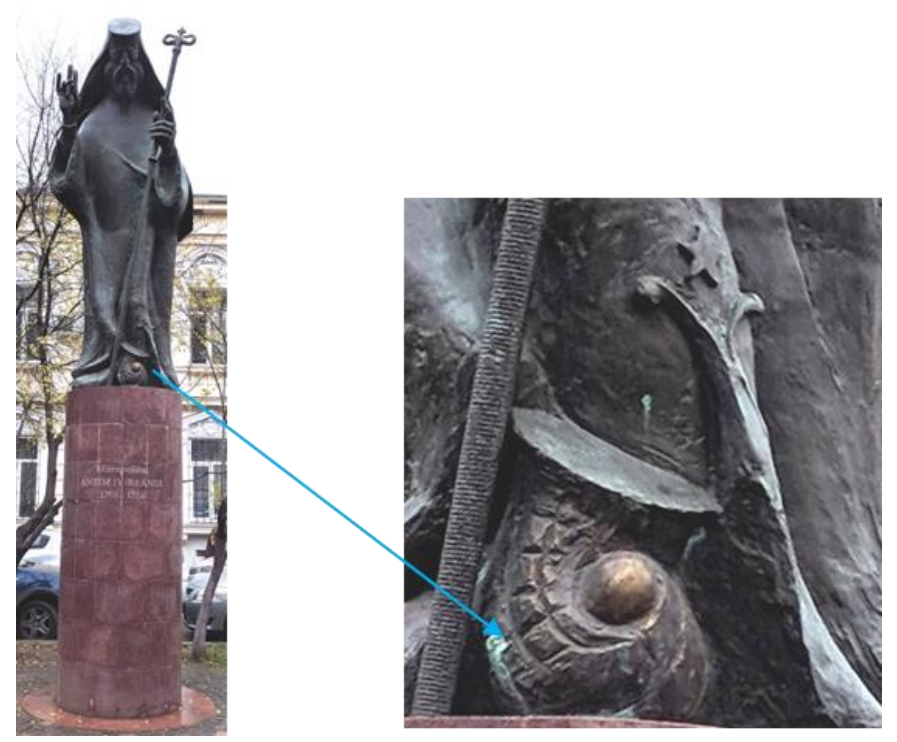

Figure 4. The elements of the coat of arms of Antim Ivireanul at the base of the statue of the metropolitan (detail)

At his feet, there appear some of the elements that belong to his coat of arms, rendered as follows: to the left, next to the bottom of the crutch, the shell of the snail, and to his right, next to the foot and placed upright, the snail positioned upside down and with a star with five rays between the two tentacles pointied with the eyes of the gastropod at the end (figure 4). The column is written on three lines: Metropolitan/ ANTIM IVIREANUL 1708-1716.

D. At the main entrance, above the carved wooden door of the Antim Monastery [8], on the carved frame between the penny and the door frame, there is the emblem of Antim: the shield, formed by a round garland of laurel leaves on the upper part of which a heraldic rose is borne, charged with the snail in the pale, coming out of the shell and having a star with six rays; the gastropod is surrounded by two palm branches arranged, each, semicircularly and crossing at the bottom (figure 5 and figure 6). 


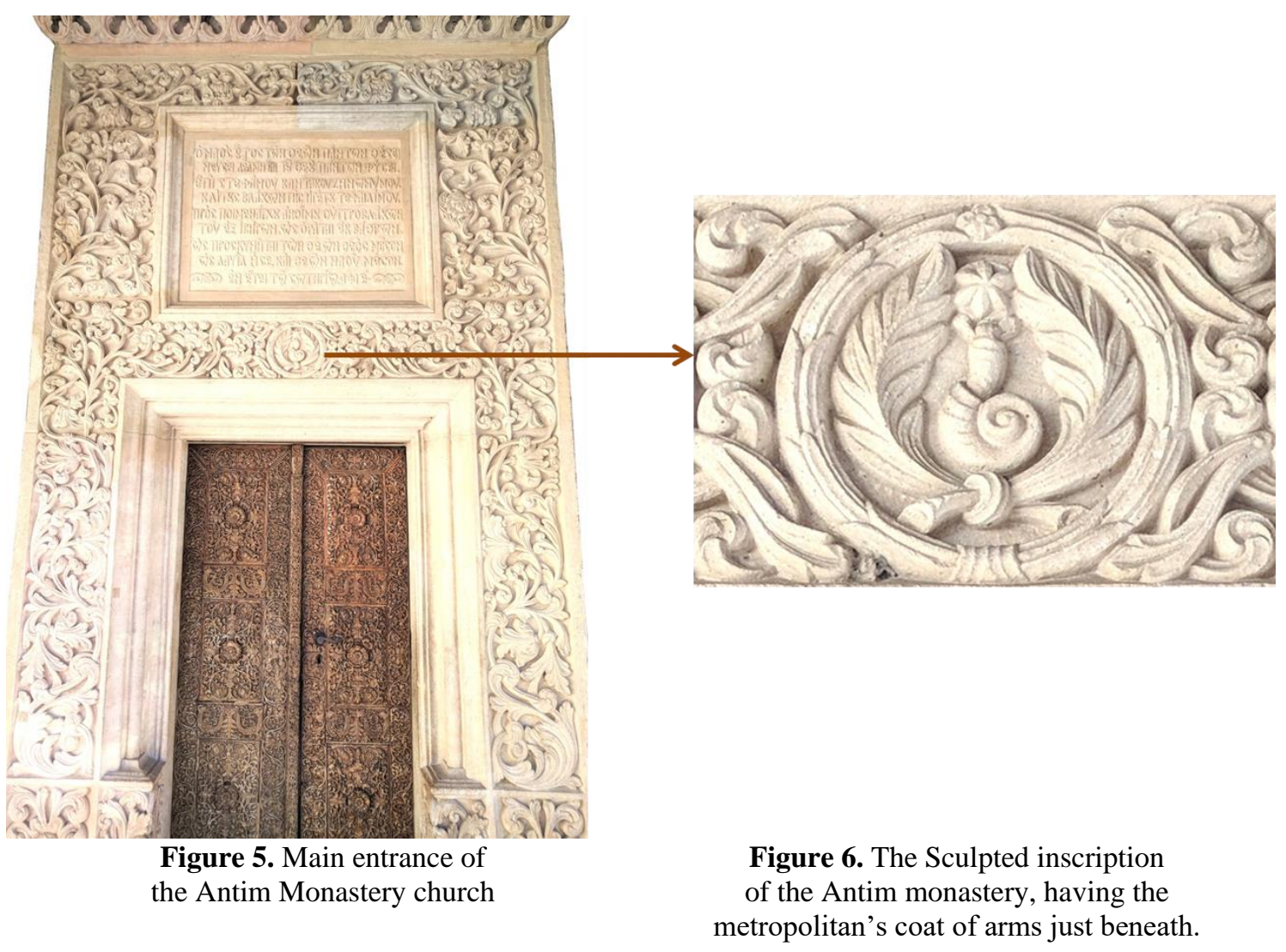

Outside, on the flanks, there are carved plants of acanthus, ending with four flowers, two on the left, two on the right. [21], [17], [20], [23], [7], [5], [19], [9].

E. At the bulletin board and at the entrance to the Antim Monastery Museum, a heraldic representation is carved in wood, which, in some ways, resembles the previous one, with yet some differences, namely: a round shield loaded with snail in the pale - vertically, coming out of the shell and having above it, just between the tentacles, a star with six rays. The snail is surrounded by two branches of laurels arranged semicircularly and crossing at the bottom. The tenants, the two figures supporting the shield, are two modillions that are attached to the flanks of the shield (figure 7).

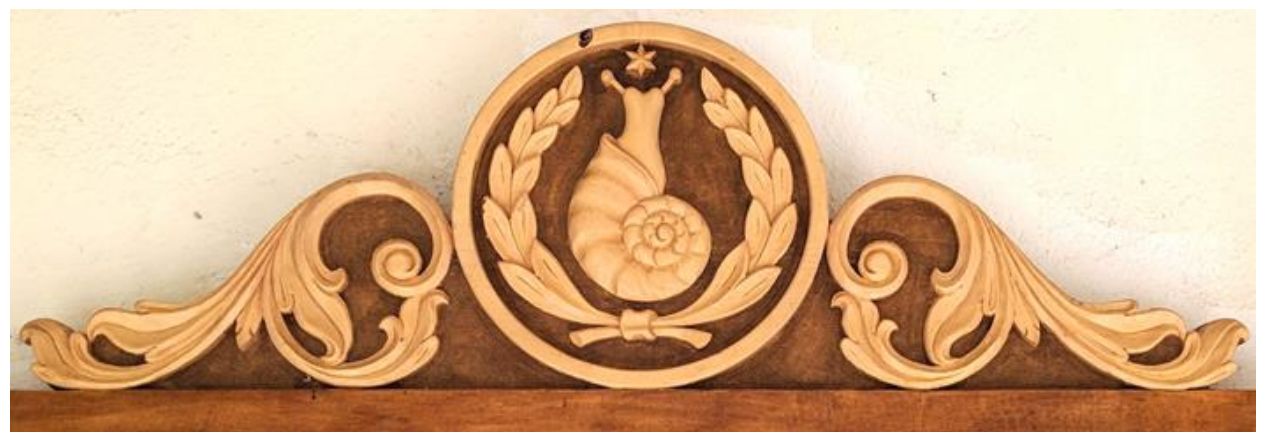

Figure 7. Antim's coat of arms situated at the bulletin board and at the entrance to the Antim Monastery Museum

F. Culture in all its forms is the one that stands out, especially in the construction of religious monuments. They are the source of attraction, being able to transmit today, from case to case, evidence of the progress of culture expressed in architecture, painting, sculpture, heraldry and other auxiliary sciences of history. The tradition of religious 
tourism is firmly established in all religions. Of course, according to the ones presented in the present case, other cultural institutions such as archives, libraries, museums holding emblems, emblems and coats of arms and which, by symbolizing the component elements, individualize their owners, are also very attractive.

\section{CONCLUSIONS}

Heraldic sources represent a distinct part of the universal cultural heritage. These sources reflect, through plastic means, the history of social communities in all its complexity. For historians and for specialists, heraldry is not only a simple way of broadening our cultural horizon, but also a means of receiving and knowing the mentality of a missing world, of understanding and interpreting the historical process reflected by each heraldic symbol. The coat of arms is a set of elements arranged according to the norms of heraldic science, meant to individualize the possessor and to express his attributions. The development of heraldry, the demonstration of the scientific character of the activity of identifying the symbols used over time, the multitude of information transmitted by these heraldic sources determined a great interest for the study of this type of signs.

Starting with the study of the evolution of the different heraldic compositions, it was possible to determine the succession of some crafts or professions, to identify the specific tools for certain areas of work, to know some significant moments in the life of the communities, of the role of certain people in the social life.

Metropolitan Antim Ivireanul was one of the most brilliant hierarchs of the Romanian Orthodox Church in the provance of Wallachia remaining a prominent personality in the cultural world.

He distinguished himself, among other personal meriths, in the field of Romanian heraldic art, not only by creating new compositions or by innovations, but especially by knowing and deciphering the meaning of the heraldic representations above, of course, in close connection with the character, thoughts and aspirations.

The enrichment or consolidation of the knowledge remains at hand for those interested in this interesting field of heraldry.

We consider that other research must be undertaken in order to identify, analyze and place other similar vestiges as well in the scientific circuit, especially since the studies on the heraldry of the Romanian clergy, although few in number, have represented a rather limited preoccupation.

\section{REFERENCES}

[1] Aretzu Paul, O mănăstire pentru un sfânt, Viața Românească, vol. 11-12, pp. 154-158, 2011

[2] Boghiu Sofian, Sfântul Antim Ivireanul și Mănăstirea Tuturor Sfinților, Editura Bizantină, București, pp. 166-167, 2005

[3] Chevaliér Jean \& Alain Ghéerbrant, Dicţionar de simboluri. Mituri, vise, obiceiuri, gesturi, forme, figuri, culori, numere, vol. II, III, Editura Artemis, Bucureşti, 1995.

[4] Clébert Jean-Paul, Bestiar fabulos. Dicţionar de simboluri animaliere, Editura ArtemisCavallioti, Bucureşti, 1995.

[5] Crișanul Emilian, Sfântul Ierarh Martir Antim Ivireanul prezent în lumea de azi prin lucrarea sa, vol. Sfântul Ierarh Martir Antim Ivireanul - ctitor de cultură și spiritualitate românească, Editura Mitropolia Olteniei, Craiova, pp. 26-36, 2018 
[6] Iliescu Florin Mihai, Mitropolitul Antim Ivireanul, misionarul culturii teologice românești, în vol. Sfântul Ierarh Martir Antim Ivireanul - ctitor de cultură și spiritualitate românească, Editura Mitropolia Olteniei, Craiova, pp. 226-230, 2018

[7] Ionescu Ion, Câteva aspecte din viața și opera lui Antim Ivireanul. Sfântul Ierarh Martir Antim Ivireanul, ctitor de limbă și cultură românească, vol. II. Promotor al scrisului și artelor bisericești, Editura Basilica, București, pp. 25-36, 2016

[8] Niculescu George, Antim Ivireanul - influențe și confluențe în spațiul geocultural sud-est european, vol. Sfântul Ierarh Martir Antim Ivireanul - ctitor de cultură și spiritualitate românească, Editura Mitropolia Olteniei, Craiova, pp. 178-184, 2018

[9] Palade Mihaela, Sfântul Martir Antim Ivireanul și mănăstirea sa, vol. Spiritualitatea mărturisitoare a culturii românești în perioada Sfântului Martir Constantin Brâncoveanu, Editura Praxis Arhiepiscopia Râmnicului, Râmnicu Vâlcea, pp. 62-98, 2014

[10] Policarp Chițulescu Policarp, Doru Bădără, Ion Marian Croitoru, Gabriela Dumitrescu \& Ioana Feodorov, Antim Ivireanul: opera tipografică, Editura Institutului Cultural Român, București, 2016.

[11] Popescu Florentin, Ctitorii brâncovenești, Editura Bibliotheca, Târgoviște, 2004

[12] Popescu Niculae, Viața și faptele Domnului Țării Românești Constantin Vodă Brâncoveanu: ediție aniversară publicată cu prilejul împlinirii a 300 de ani (1714-2014) de la martirizarea Sfântului Voievod Constantin Brâncoveanu, împreună cu cei patru fii ai săi, Constantin, Ștefan, Radu și Matei, și a sfetnicului Ianache Văcărescu, Editura Basilica, Patriarhia Româna, București, 2014.

[13] Sacerdoțeanu Aurelian, Antim Ivireanul arhivist, bibliotecar și topograf, Glasul Bisericii”, vol. XXIII, nr. 3-4, pp. 239-243, 1964

[14] Șerbănescu Niculae, Constantin Brâncoveanu, domnul Țării Românești - 275 de ani de la moartea sa martirică 1714 - 15 august - 1989, în „Biserica Ortodoxă Română”, issue. 7-10, pp. 98-158, 1989

[15] Șerbănescu Niculae, Constantin Vodă Brâncoveanu, domnitorul Țării Românești (16881714). Cu prilejul comemorării a 330 de ani de la nașterea sa și a 270 de ani de la moarte 1654 1714 - 1984 - 15 august, Biserica Ortodoxă Română, issue. 8-10, pp. 660-683, 1984

[16] Strachină Olivia, Facsimilarea documentelor de arhivă - o problemă de actualitate, Revista Arhivelor, XLIX, vol. XXXIV, issue. 1, 1972

[17] Ștrempel Gabriel, Antim Ivireanul, Editura Academiei Române, București, 1997.

[18] Szemkovics Laurentiu-Stefan, Teodorescu Camelia, Alexandra Grecu, Karina Gruia, Alina Mareci \& Nicoleta Bira, The relevance of the historical monuments in the development of the cultural tourism in the main cities of the region of Oltenia, Romania, Quaestus Journal, Timisoara, Romania, vol. 12, issue. 2, pp. 42-54, 2018

[19] Szemkovics Laurențiu-Ștefan, Patru documente de la Antim Ivireanul, în vol. Sfântul Ierarh Antim Ivireanul - ctitor de cultură și spiritualitate românească, Editura Mitropolia Olteniei, Craiova, Romania, vol. 1, issue. 1, pp. 192-205, 2018

[20] Teodorescu Camelia \& Szemkovics Laurentiu-Stefan, The Ethno-creativity in the Pilot Centers in Romania and their Role in the Development of Cultural Tourism and the Educational Process, Forum geografic Geographical studies and environment protection research, Craiova, Romania, vol. 16, issue.1, pp. 88-97, 2017

[21] Teodorescu Camelia, Octavian Teodorescu, Nicoleta Bira, Badea Alin \& Badea Livia Florina, Religious and cultural tourism and the socio-economic and educational implications, Quaestus Multidisciplinary Research Journal, Romania, vol. 8, pp. 227-285, 2016

[22] Teodorescu Camelia, Radu-Daniel Pintilii, Peptenatu Daniel, Teodorescu Octavian \& Toma Sorin George, Popularizing Cultural Identity Through Religious Tourism-Socio-Economic and 
Educational Implications, International Multidisciplinary Scientific GeoConference: SGEM: Surveying Geology \& mining Ecology Management, Bulgaria, vol.3, pp 947-954, 2016

[23] Velculescu Cătălina \& Ileana Stănculescu, Animale între numere și flori, în Lumea animalelor. Realități, reprezentări, simboluri, Editura Universității „Alexandru Ioan Cuza” Iași, Romania, pp. 359-389, 2012

[24] Velculescu Cătălina \& Ileana Stănculescu, Iuliana Damian, Grifoni şi trandafiri în vremea lui Constantin Brâncoveanu, vol. Spiritualitatea mărturisitoare a culturii românești în perioada Sfântului Martir Constantin Brâncoveanu, Editura Praxis, Arhiepiscopia Râmnicului, Râmnicu Vâlcea, Romania, pp. 173-200, 2014

[25] Vicovan Ion, Filantropia socială, culturală și misionară a Sfinților Martiri Constantin Brâncoveanu și Antim Ivireanul, în vol. Spiritualitatea mărturisitoare a culturii românești în perioada Sfântului Martir Constantin Brâncoveanu, Editura Praxis, Arhiepiscopia Râmnicului, Râmnicu Vâlcea, Romania, pp. 160-172, 2014 